\title{
Information sharing, lending and defaults: Cross-country evidence
}

\author{
Tullio Jappelli ${ }^{\mathrm{a}, \mathrm{b}, *}$, Marco Pagano ${ }^{\mathrm{a}, \mathrm{b}}$ \\ ${ }^{a}$ CSEF, Università di Salerno, 84084 Fisciano, Salerno, Italy \\ b CEPR, London, UK
}

Received 15 February 2000; accepted 11 March 2001

\begin{abstract}
Theory predicts that information sharing among lenders attenuates adverse selection and moral hazard, and can therefore increase lending and reduce default rates. Using a new, purpose-built data set on private credit bureaus and public credit registers, we find that bank lending is higher and credit risk is lower in countries where lenders share information, regardless of the private or public nature of the information sharing mechanism. We also find that public intervention is more likely where private arrangements have not arisen spontaneously and creditor rights are poorly protected.
\end{abstract}

(c) 2002 Elsevier Science B.V. All rights reserved.

JEL classification: D82; G21; G28

Keywords: Information sharing; Credit market; Default rate

\section{Introduction}

A large body of literature shows that asymmetric information between borrowers and lenders can prevent the efficient allocation of credit. Lenders are often unable to observe the characteristics of borrowers, including the riskiness of their investment projects, and this induces adverse selection problems. Lenders may also be unable to control the actions that borrowers take after receiving a loan. A borrower may relax his effort to prevent default or hide the proceeds of his investment to keep from

\footnotetext{
${ }^{*}$ Corresponding author. Fax: 39-089-963169.

E-mail address: tullioj@tin.it (T. Jappelli).
} 
having to repay his debts. Even a solvent borrower may try to avoid repayment if the lender cannot observe or sanction his actions. The consequence is that lenders may ration credit or charge high borrowing rates.

It is often assumed that the only way lenders can overcome these informational problems is to produce information about their customers via screening and monitoring. For instance, they can interview applicants, visit their business before and after granting the loan, and gather information from public records. If lenders operate on a large scale, they can use these data for statistical risk management to grant and price loans on the basis of past performance.

Most of the literature neglects exchange of information with other lenders as an alternative way to learn about one's own customers. This exchange can be voluntary or imposed by regulation. When it occurs spontaneously, it is effected by information brokers, known as "credit bureaus", which operate on the principle of reciprocity, collecting, filing and distributing the information supplied voluntarily by their members. In many countries a great deal of informational exchange also occurs via "public credit registers". These are generally managed by central banks, with compulsory reporting of data on borrowers, which are then processed and returned to the lenders.

Previous theoretical research, summarized in Section 2, shows that information sharing between lenders can foster credit activity and increase borrowers' incentives to repay, but no empirical investigation of such effects exists to this date. To fill this gap, in this paper we use a new international database to document the correlations between the presence of credit bureaus or public credit registers, lending activity and default rates.

Sections 3 and 4 describe our data set, which we collected via questionnaires directed to private credit bureaus and central banks. Borrower coverage and the type of data exchanged vary considerably over time and between countries. Lenders commonly exchange data about past defaults or arrears. Sometimes they also share data about customers' outstanding liabilities, maturities, and details about borrowers' credit history. In Sections 5 and 6 we correlate information sharing with lending and credit risk, considered as a proxy for the default rate. Private and public information sharing is associated with broader credit markets and lower credit risk. The empirical analysis reveals that private and public information sharing arrangements have no differential correlation on credit market performance. One way to interpret this finding is that public credit registers and private credit bureaus are substitutes. This leads us to investigate directly whether the absence of private credit bureaus prompts regulators to establish public credit registers or to widen the scope of their operation. Probit and Tobit regressions reported in Section 7 show that these hypotheses are consistent with the data. Section 8 summarizes our main findings.

\section{Review of theoretical models}

Recent theoretical research suggests a threefold effect of lenders' exchange of information about borrowers. First, credit bureaus improve banks' knowledge of ap- 
plicants' characteristics and permit more accurate prediction of repayment probability. This allows lenders to target and price their loans better, easing adverse selection problems. Second, credit bureaus reduce the informational rents that banks could otherwise extract from their customers. They tend to level the informational playing field within the credit market and force lenders to price loans more competitively. Lower interest rates increase borrowers' net return and augment their incentive to perform. Third, credit bureaus work as a borrower discipline device: every borrower knows that if he defaults his reputation with all other potential lenders is ruined, cutting him off from credit or making it more expensive. This mechanism also heightens borrowers' incentive to repay, reducing moral hazard.

Here we review these three effects of information sharing. In the pure adverse selection model developed by Pagano and Jappelli (1993), information sharing improves the pool of borrowers, decreases defaults and reduces the average interest rate. In the model, each bank has private information about the credit worthiness of local residents but no information about immigrants, who therefore face adverse selection. If banks exchange their private information about residents, they can lend safely to immigrants as well, so the default rate decreases. The effect on lending is ambiguous, however. The volume of lending may increase or decrease, because when banks exchange information about borrowers' types, the implied increase in lending to safe borrowers may fail to compensate for the reduction in lending to risky types. Banking competition tends to strengthen the positive effect of information sharing on lending: when credit markets are contestable, information sharing reduces informational rents and increases competition, which in turn leads to greater lending. ${ }^{1}$

The other two effects arise in the presence of moral hazard. Information sharing can reinforce borrowers' incentives to perform, either via a reduction of banks' rents or through a disciplinary effect. The exchange of information between banks reduces the informational rents that banks can extract from their clients within lending relationships. Padilla and Pagano (1997) make this point in the context of a two-period model where banks are endowed with private information about their borrowers. This informational advantage confers to banks some market power over their customers, and thereby generates a hold-up problem: since banks are expected to charge predatory rates in the future, borrowers exert low effort to perform, leading to high default and interest rates, and possibly to the collapse of the credit market. By committing to exchange information about borrowers' types, they restrain their own future ability to extract informational rents. This reduces the probability of default of

\footnotetext{
${ }^{1}$ This model also delivers predictions about lenders' incentives to create a credit bureau. Lenders have a greater incentive to share information when the mobility of credit seekers is high and when the potential demand for loans is large. Technical innovations that reduce the cost of filing, organizing and distributing information should foster credit bureaus' activity. Banking competition, by contrast, might inhibit the appearance of credit bureaus: with free entry, a bank that supplies information about its customers to a credit bureau is in effect helping other lenders to compete more aggressively. This reduces the expected gain from information sharing and could deter the creation of a credit bureau. Pagano and Jappelli (1993) bring international and historical evidence to bear on these predictions.
} 
each borrower and the interest rate he is charged, and increases total lending relative to the regime without information sharing.

An effect on incentives exists even when there is no hold-up problem. This effect is present when banks, instead of exchanging information about borrowers' types, communicate to each other data about past defaults. Padilla and Pagano (2000) show that this creates a disciplinary effect. When banks share default information, default becomes a signal of bad quality for outside banks and carries the penalty of higher interest rates. To avoid this penalty, entrepreneurs exert more effort, leading to lower default and interest rates and to more lending. ${ }^{2}$

In this model, disclosing information about borrowers' quality, instead, has no effect on default and interest rates, in contrast with the result of Padilla and Pagano (1997). Ex-ante competition is assumed to eliminate the informational rents of banks anyway, so that their customers' overall interest burden cannot be reduced further. As a result, when information about their quality is shared, borrowers have no reason to change their effort level, and equilibrium default and interest rates stay unchanged. Information sharing about borrowers' characteristics can even reduce lending. When they share information, banks lose all future informational rents and therefore require a higher probability of repayment to be willing to lend. So the credit market may collapse in situations in which it would be viable under no information sharing.

This suggests that sharing data on defaults rather than borrowers' characteristics can have quite different effects on the probability of default. The disciplinary effect arises only from the exchange of default information. To the extent that banks also share data on borrowers' characteristics, they actually reduce the disciplinary effect of information sharing: a high-quality borrower will not be concerned about his default being reported to outside banks if these are also told that he is a high-quality client. But, as discussed above, exchanging information about borrowers' characteristics may reduce adverse selection or temper hold-up problems in credit markets, and thereby reduce default rates.

On the whole, all three models agree on the prediction that information sharing (in one form or another) reduces default rates, whereas the prediction concerning its effect on lending is less clear-cut. However, even the prediction about default is unambiguous only if referred to the probability of default of an individual borrower. When one considers the average default rate, the prediction may be overturned by composition effects. Suppose that information sharing gives access to credit to lower-grade borrowers. Even though each borrower's probability of default is lower, the aggregate default rate may increase because the relative weight of lower-grade borrowers increases. Since the data used in the next sections concern aggregate measures of the default rate, this composition effect may introduce a bias against finding a negative correlation between information sharing and defaults.

\footnotetext{
${ }^{2}$ In this model there is no holdup problem because initially banks have no private information about credit seekers, and ex ante competition dissipates any rents from information acquired in the lending relation.
} 
Before analyzing the correlation between information sharing, lending and defaults, we proceed to describe the main features of private and public information sharing arrangements, and their diffusion around the world.

\section{Private information sharing arrangements}

In a number of countries, lenders (banks, finance companies, credit card companies, retailers, suppliers extending trade credit) routinely share information on the creditworthiness of their borrowers through credit bureaus, information brokers that in some cases are set up and owned by the lenders themselves and in others operated independently for profit by a third party. Lenders supply the bureau with data about their customers. The bureau collates this information with data from other sources (courts, public registers, tax authorities, etc.) and compiles a file on each borrower. The lenders that contribute data can later obtain a return flow of consolidated data about a credit applicant by requesting a "credit report" from the bureau. Nowadays this two-way flow of data between lenders and the bureau is effected electronically.

It is the exchange of information between lenders that distinguishes a credit bureau from other agencies that collect and process valuable information from public sources and private investigators. Credit bureaus often do collect and process such data, but this is not their distinguishing characteristic.

Lenders who provide their private information to credit bureaus are granted access to the common database insofar as the data provided are timely and accurate. Credit bureaus are exposed to a potential conflict of interest, especially when they are owned by the lenders themselves: each lender would like to exploit the information provided by other lenders without disclosing his own. This explains why sanctions are invariably threatened to any credit granter who fails to supply data or provides inaccurate information. Sanctions range from fines to loss of membership and hence denial of access to the bureau's files. In other words, credit bureaus are based on the principle of reciprocity, which is generally stated in the contractual agreement between the bureau and credit grantors. ${ }^{3}$ Most credit grantors do supply their information regularly, particularly those that have accounts receivable on tape.

Around the world, arrangements of this type are found both in the household credit market and in business lending, in varying degrees and with different institutional features. These are described and documented below.

\subsection{Personal loans and small business loans}

Personal and small business loans are characterized by a large number of applicants whose desired loan size is not large enough to warrant individual assessment. In these markets, screening can benefit greatly from statistical analysis of applicants'

\footnotetext{
${ }^{3}$ There are exceptions, however. At one time, American Express declined to share its information with the credit bureaus, but because it was willing to buy reports in large quantities, the bureaus kept on selling reports to that firm. This situation later changed and American Express now provides data on its own customers.
} 
characteristics and credit histories as predictors of repayment, and such analysis is feasible precisely because of the large number of standard loans. Credit bureaus, which pool data from many lenders and for several years, own the ideal database for estimating statistical models of risk management, which explains why credit bureaus have generally originated precisely in the consumer credit market. They are now increasingly active in the small business and trade credit markets as well.

A credit bureau can issue several kinds of credit reports, depending on the information gathered, the type of credit application (consumer credit, house mortgage, small business loan, etc.) and, most importantly, the amount of detail requested by the lender. Reports range from simple statements of past defaults or arrears "black" or "negative" data - to detailed reports on the applicant's assets and liabilities, guarantees, debt maturity structure, pattern of repayments, employment and family history - "white" or "positive" data. Naturally the price of a credit report depends on the amount of detail. Prices for basic credit reports are currently quite low, averaging about 1 dollar in the US and the UK, 2 dollars in Italy, and more than 3 dollars for local credit bureaus in Argentina.

Figs. 1 and 2 give examples of the most basic type of credit report, reproduced from a publication of the largest credit bureau in Australia, which only collects and reports negative information. Fig. 1 shows an individual credit file for a person with several credit problems: three members of the bureau reported default, there was a debt judgment, and he appears as director of a failed company. The bottom part of the report shows previous queries to the bureau by various lenders. Fig. 2 refers to a small company. It shows the main shareholders and directors, with cross references to the individual files that the bureaus has recorded in their names. The company has been reported as insolvent by a bureau member and has pledged a security over its assets to a bank.

The more sophisticated credit bureaus also use statistical models to produce and sell "credit scoring" services, by which they rate borrowers according to characteristics and credit history. Such scores were initially developed by credit grantors mainly for deciding on applications. Where positive information is also available, the models are now intensively also used to promote financial instruments, price loans, and set and manage credit limits.

To gather more information about their operations around the world, we sent a questionnaire (reported in Appendix A) to credit bureaus in 49 countries. ${ }^{4} \mathrm{We}$ received responses from credit bureaus in 39 countries; for 4 more, we obtained data from other sources (Internet sites, published information, etc.). ${ }^{5}$ The data obtained are reported in Table 1, which displays, by country, the year in which credit bureaus were first established, the type of information exchanged (black or white) and the number of credit reports issued by credit bureaus.

\footnotetext{
${ }^{4}$ The list of countries is the same as in La Porta et al. (1997). This choice is dictated by the need to merge our data on information sharing with data on other institutional determinants of lending and default.

${ }^{5}$ Detailed information on European countries is reported in a background paper (Jappelli and Pagano, 2000).
} 
FILE NUMBER - 64610042 REF 3664-3186

HARRISON,THOMAS,RONALD,M,M,KRISTINA

SUBJECT BORN - 100850,LIC NO-2421PS

SPOUSE BORN - 250164

EMPLOYMENT - SERVICEMAN,GAZEBO WHOLESALERS PL

ADDRESS - 35,LAND,BONNYRIGG,NSW

PREVIOUS - 48,GERORGE,DANDENONG,VIC

\section{DIRECTORSHIP DETAILS}

DATE

130886 MRT - GEZEBO WHOLESALERS PL (IN LIQ.) CC-64608113

\section{MEMBER DEFAULT REPORTS}

$\begin{array}{lllllll}\text { DATE } & \text { NAME } & \text { AC } & \text { AMNT } & \text { DF } & \text { REF. NO. } & \text { DTR PAID } \\ 140388 & \text { STANDARD CHART LOSS REC NSW } & \text { L } & 5431 & \text { PD } & \text { LLR0040LS } & \text { MRT } \\ \text { 040687 } & \text { AGC FIVE DK NSW } & \text { L } & 7314 & \text { R } & \text { L1070515135 } & \text { MRT } \\ \text { 260186 } & \text { ESANDA ADMIN SYD NSW } & \text { RM } & 6448 & \text { RL } & 241174159 & \text { T\&K }\end{array}$

\section{JUDGEMENTS}

DATE NAME AMNT DF PLAINT. NO. DTR PAID

$150487 \quad 9037$ DJ 15648/86/METN MRT

NOTE: ALLEGED DEBT(S) MAY HAVE BEEN PAID SINCE RECORDED, OR ARE POSSIBLY

DISPUTED. CHECK WITH CREDITORS FOR CONFIRMATION.

\section{CREDIT ENQUIRIES}

$\begin{array}{lllll}\text { DATE } & \text { NAME } & \text { AC } & \text { AMNT DTR } \\ 140688 \text { CITYCORP FIN HURTSVILLE NSW. } & \text { L } & 8727 & \text { T\&K } \\ 131287 & \text { AGC FIVE DOCKK NSW } & \text { L } & 8700 & \text { T\&K } \\ \text { 231087 JAOHN'S MOTOR NSW } & \text { HM } & 7000 & \text { T\&K } \\ \text { 111186 WESTPAC WESTERN NSW } & \text { CC } & 0 & \text { MRT } \\ \text { 221185 ITICORP FIN SYDNEY NSW } & \text { L } & 1717 & \text { MRT } \\ \text { 150685 } & \text { PERMANENT FIN CORP NSW } & \text { HB } & 15300 & \text { MRT } \\ 310784 & \text { AGC FIVE DOCK NSW } & \text { L } & 18000 & \text { MRT } \\ \text { 230484 } & \text { ESANDA ADMIN VIC } & \text { RM } & 19000 & \text { MRT }\end{array}$

KEY TO THE INITIALS USED IN THE REPORT

$\begin{array}{llll}\text { AC } & \text { - ACCOUNT TYPE } & \text { L } & \text { - LEASE ACCOUNT } \\ M & \text { - MONTHLY ACCOUNT } & \text { HM } & \text { - HIRE PURCHASE MOTOR VEHICLE } \\ \text { T } & \text { - TERMS ACCOUNT } & \text { RM } & \text { - REAL ESTATE MORTGAGE } \\ \text { HB } & \text { - HIRE PURCHASE BOAT } & \text { CC } & \text { - CREDIT CARD } \\ \text { AMNT } & \text { - AMOUNT OWING OR APPLIED FOR } & \text { DF } & \text { - REASON FOR REPORTING } \\ \text { PD } & \text { - REGULAR PAYMENT DEFAULT } & \mathrm{R} & \text { - REPOSSESSION } \\ \text { RL } & \text { - REPOSSESION LOSS } & \text { DJ } & \text { - DISTRICT COURT JUDGEMENT } \\ \text { LA } & \text { - LEGAL ACTION } & \text { DTR } & \text { - WHO IS THE DEBTOR } \\ \text { MRT } & \text { - DEBTOR IS MR. T. HARRISON } & \text { T\&K } & \text { - DEBTOR IS THOMAS AND KRISTINA }\end{array}$

Fig. 1. A standard credit report on an individual. (Source: Credit Reference Association of Australia Ltd.)

The table shows that in some countries lenders exchange a massive amount of negative and positive information in the consumer credit market: Canada, the US, the UK, Japan, Germany, South Africa, Sweden and Switzerland have the highest number of credit reports per person, and lenders have exchanged information for decades at least and in many cases the better part of a century. Credit bureaus have 


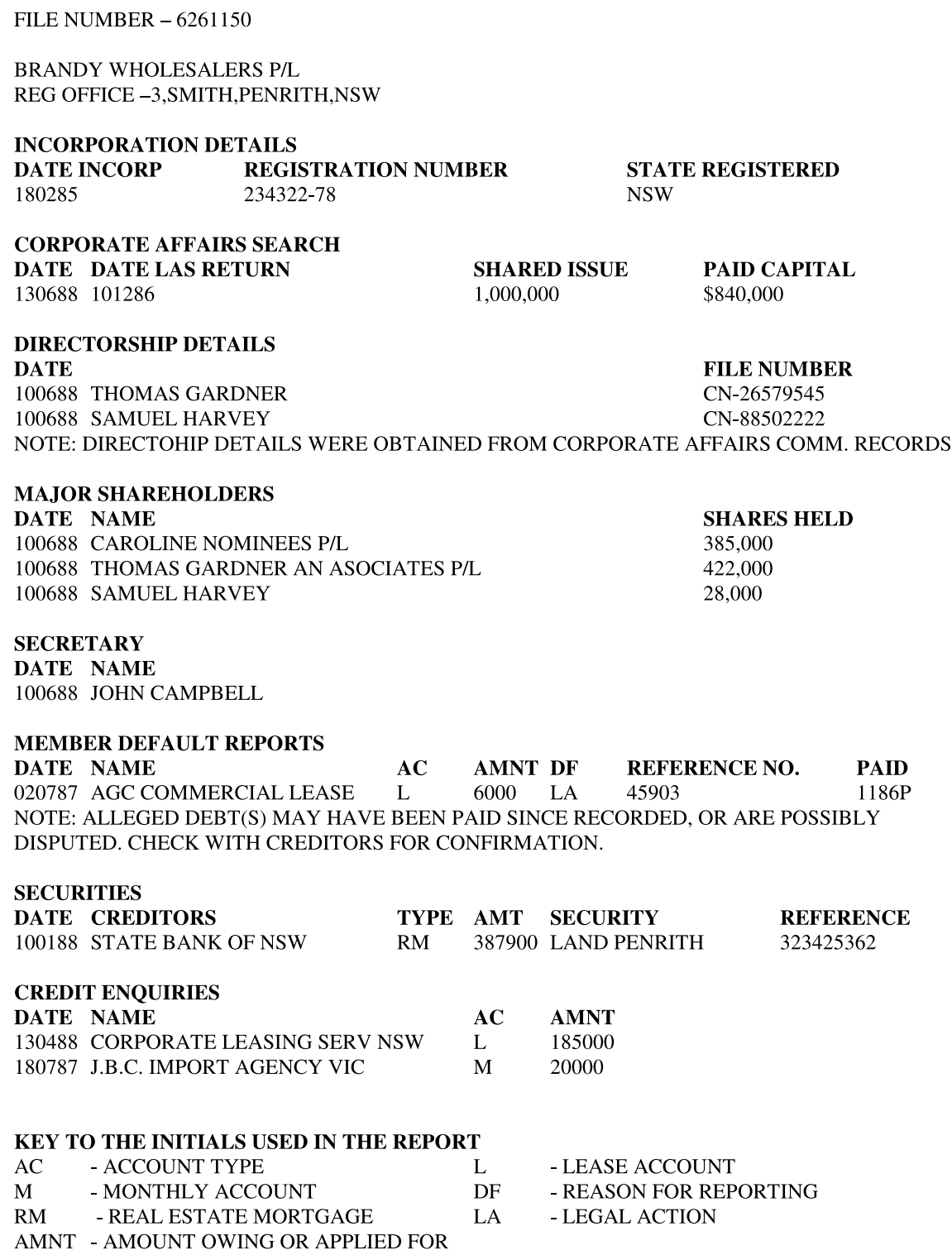

Fig. 2. A standard credit report on a company. (Source: Credit Reference Association of Australia Ltd.)

also operated for several decades in Argentina, Brazil, Finland, the Netherlands, and Australia but on a smaller scale. In Italy credit bureaus are a relatively new phenomenon, but have taken on growing importance in recent years. In some Latin American and Asian countries, credit bureaus are in their infancy, either non-existent or operating on a small scale and exchanging mainly black information. 
Table 1

Private credit bureaus around the world

\begin{tabular}{|c|c|c|c|}
\hline Country & Starting date & $\begin{array}{l}\text { Type of information } \\
\text { shared }\end{array}$ & $\begin{array}{l}\text { Credit reports: level (millions)/per- } \\
\text { cent of population }(\mathrm{yr})\end{array}$ \\
\hline Argentina & 1950 & $\mathrm{~B}-\mathrm{W}$ & $1.2 / 3.4$ (1997) \\
\hline Australia & 1930 & B & $5.8 / 34.0(1990)$ \\
\hline Austria & 1860 & $\mathrm{~B}-\mathrm{W}$ & N/A \\
\hline Belgium & 1987 & B & 10.6/104.8 (1998) \\
\hline Brazil & 1996 & B & $200.0 / 128.3(1997)$ \\
\hline Canada & 1919 & $\mathrm{~B}-\mathrm{W}$ & 24.0/82.7 (1998) \\
\hline Chile & 1990 & $\mathrm{~B}-\mathrm{W}$ & 7.0/49.3 (1997) \\
\hline Denmark & 1971 & B & $2.6 / 50.3(1996)$ \\
\hline Finland & 1900 & B & $3.5 / 70.2(1990)$ \\
\hline France & None & & \\
\hline Germany & 1927 & $\mathrm{~B}-\mathrm{W}$ & 48.0/59.1 (1996) \\
\hline Greece & None & & \\
\hline Egypt & None & & \\
\hline Hong Kong & 1982 & B & N/A \\
\hline India & N/A & N/A & N/A \\
\hline Ireland & 1963 & $\mathrm{~B}-\mathrm{W}$ & $0.8 / 22.5$ (1996) \\
\hline Israel & None & & \\
\hline Italy & 1990 & $\mathrm{~B}-\mathrm{W}$ & 2.6/4.6 (1996) \\
\hline Japan & 1965 & $\mathrm{~B}-\mathrm{W}$ & $149 / 121.5(1990)$ \\
\hline Jordan & None & & \\
\hline Kenya & None & & \\
\hline Mexico & 1997 & N/A & N/A \\
\hline Netherlands & 1965 & $\mathrm{~B}-\mathrm{W}$ & 9.8/64.1 (1996) \\
\hline New Zealand & N/A & B & N/A \\
\hline Nigeria & None & & \\
\hline Norway & 1987 & B & $0.5 / 12(1990)$ \\
\hline Pakistan & None & & \\
\hline Peru & 1995 & $\mathrm{~B}-\mathrm{W}$ & N/A \\
\hline Philippines & 1982 & B & N/A \\
\hline Portugal & N/A & $\mathrm{B}-\mathrm{W}$ & N/A \\
\hline Singapore & 1978 & B & N/A \\
\hline South Africa & 1901 & $\mathrm{~B}-\mathrm{W}$ & N/A \\
\hline South Korea & 1985 & $\mathrm{~B}-\mathrm{W}$ & N/A \\
\hline Spain & 1994 & B & N/A \\
\hline Sri Lanka & None & & \\
\hline Sweden & 1890 & $\mathrm{~B}-\mathrm{W}$ & $2.2 / 26.0(1990)$ \\
\hline Switzerland & 1968 & $\mathrm{~B}-\mathrm{W}$ & $1.7 / 24.1$ (1997) \\
\hline Taiwan & 1975 & $\mathrm{~B}-\mathrm{W}$ & N/A \\
\hline Thailand & None & & \\
\hline Turkey & None & & \\
\hline UK & 1960 & B-W & 60.0/104.8 (1989) \\
\hline Uruguay & 1950 & $\mathrm{~B}$ & N/A \\
\hline US & 1890 & $\mathrm{~B}-\mathrm{W}$ & $600.0 / 228.1$ (1997) \\
\hline Venezuela & N/A & N/A & N/A \\
\hline Zimbabwe & None & & \\
\hline
\end{tabular}

Figures are based on a questionnaire sent to the main credit bureaus in each country, whose names are not reported for reasons of confidentiality. When two or more credit bureaus responded for the same country, the information was merged as follows. The starting date refers to the oldest credit bureau in the country. The type of information shared refers to the 1990s and is defined as "black" (B) if it refers to defaults and 
Table 1 (continued)

arrears, and "white" (W) if it also includes other information, such as debt exposure. Credit reports are the number of credit reports issued by all the credit bureaus in the country (if available); otherwise, by the credit bureaus responding in that country.

Our questionnaires also elicit qualitative information on the structure and evolution of the credit bureau industry, which is not reported in the table. In most countries there is a strong concentration. A few countries have just one large credit bureau (Australia, Germany, Argentina, Brazil, Finland, and Ireland). In the US, $\mathrm{UK}$, and Japan competition is limited to two or three large vendors. This process of concentration is relatively recent. Where the industry has the longest history (e.g., in the US), it began with local credit bureaus, progressively merging into larger entities. This reflects economies of scale (the larger the credit bureau, the more complete and accurate its information), as well as recent advances in information technology and the elimination of barriers between local credit markets. In the early 1990s concentration began to extend beyond national boundaries: the top three US bureaus (Equifax, Experian and Trans Union) acquired national credit bureaus throughout Latin America and in parts of Europe and Asia.

The questionnaires also gather information on ownership structure. In the US, Brazil and Argentina the major credit bureaus are for-profit operations owned by private entrepreneurs, although there are also several local non-profit bureaus owned by chambers of commerce or merchants' associations. In Japan and in most of Europe, credit bureaus are typically incorporated as private companies owned by a consortium of lenders. In Finland and Belgium, they are operated or licensed by government agencies. With the process of cross-border acquisitions of local credit bureaus, especially by the large US vendors, the industry is becoming increasingly profit-oriented.

The international differences in the presence and activity of credit bureaus have several complementary explanations. Pagano and Jappelli (1993) document that the number of credit reports per capita are largest where household mobility is highest. This accords with the idea that the benefit of establishing a credit bureau is greatest where each bank is confronted by a large number of unknown customers, which is the case in countries where borrowers are very mobile.

Fear of competition may also inhibit information sharing. When lenders agree to supply data to a credit bureau they lose the monopoly power attached to exclusive customer information, unless they are well protected by other barriers to entry. So lenders' incentives to pool information are greater when local credit markets are segmented by regulation, as in the US, than when banks are free to compete nationwide, as in most European countries.

A further element that has historically affected the development of credit bureaus is the degree of privacy protection accorded to prospective borrowers. The activities of credit bureaus are regulated almost everywhere so as to prevent violation of privacy and civil liberties. Privacy laws contemplate a wide range of consumer guarantees, such as limits on access to files by potential users, bans on white information (e.g., in Finland and Australia), compulsory elimination of individual files after a 
set time ( 7 years in the US, 5 in Australia), bans on gathering certain kinds of information (race, religion, political views, etc.) and right to access, check and correct one's own file. 6

Finally, also the degree of protection of creditor rights may have affected the development of credit bureaus. Where the legal and judicial systems give poor protection to creditors, debtors may be tempted to default on their obligations even when they have the means to repay. As we argue in Section 2, credit bureaus can attenuate moral hazard in credit relations, by creating a private disciplinary system in place of defective public sanctions.

\subsection{Corporate loans}

The information needed to assess the creditworthiness of companies is by its very nature more complex and less standardized than for households. Therefore in the case of business loans credit bureaus generally take a more active role in the production of information, collating credit market data received from lenders and suppliers together with balance sheet data and information from the company itself and from public sources about shareholders and managers. The positive component of a credit report for a company is typically much larger than for an individual, and the nature of the credit bureaus in this market segment is different. Rather than provide standard credit reports and statistical risk management, here credit bureaus become rating agencies, gathering and processing information from a variety of sources, including lenders and suppliers.

This very active role in the production, processing, and marketing of information may explain why the credit agencies that treat corporate loans are typically profitoriented businesses, not lenders' cooperative arrangements. The largest of these agencies worldwide is Dun \& Bradstreet (D\&B). Formed in 1933 through the merger of two credit reporting agencies (R.G. Dun \& Co., formed in 1841, and the Bradstreet Company), today D\&B maintains a global database that covers 48 million businesses, 10 million of them in the US. It provides a wide range of services, from the assessment of credit risk and suppliers' reliability to the management of credit and accounts receivables. A standard D\&B business information report (available online via the Internet) contains payment history, financial condition, business history, management experience, details on lines of business, parent company and subsidiaries, public records, etc.

\footnotetext{
${ }^{6}$ As far as access limits are concerned, there appear to be three levels of privacy protection. The replies to our questionnaire indicate that there are low-protection countries, such as Argentina, where anyone can access all debtors' data regardless of the purpose of investigation. In such medium-protection countries as the US, data can be accessed only for an "admissible purpose", essentially the granting of credit. A higher level of privacy protection may be embodied in the further requirement of the borrower's explicit consent to access his file. This principle is enshrined in the legislation of several European countries and in the Directive 95/46 of the European Parliament on "the protection of individuals with regard to the processing of personal data and on the free movement of such data". In some countries (such as France, Israel and Thailand) safeguards for consumer privacy are so strong that regulation has impeded the emergence of private credit bureaus.
} 


\section{Public credit registers}

Most countries have public registers for real estate collateral (mortgages) to protect the seniority rights of collateralized creditors, and bankruptcy information is publicly disseminated to alert present creditors and potential new lenders. ${ }^{7}$ These can be considered as basic forms of publicly enforced information sharing. But in several countries government authorities have taken a much more active role in fostering the exchange of information between lenders, creating formal public credit registers (PCRs), which operate in many respects like credit bureaus.

The PCRs are managed by central banks (except in Chile, Costa Rica and Peru, where they are operated by the banking supervisory authorities; in Finland, the credit register is contracted out to a private company, and therefore we do not consider it as a PCR). Access to the PCR is granted only to authorized central bank staff (mainly for surveillance reasons and under tight confidentiality rules) and to the reporting financial institutions. ${ }^{8}$ This creates a two-way flow of data between credit grantors and the PCR, much as in the case of private credit bureaus.

The key difference from credit bureaus is that participation in the PCR is compulsory, and its rules are not contracted, but imposed by regulation (except in Sri Lanka, where participation is voluntary). This implies a second important difference, namely that PCRs have universal coverage (all loans above a threshold amount must be reported at specified intervals), but the information consists mainly of credit data and is disseminated in consolidated form (total loan exposure of each borrower, no details on individual loans). Credit bureaus are less complete in coverage but offer details on individual loans and merge credit data with other data.

Table 2 sets forth the main characteristics of PCRs around the world, based on a questionnaire submitted to 49 central banks, of which 46 have responded (for the questionnaire, see Appendix); 19 operate a PCR and 27 do not. PCRs are common in continental Europe and Latin America, absent in Anglo-Saxon countries. Most have been created in the last two decades, except for Germany (1934), Italy (1964) and Mexico (1964). The newcomers are mostly located in Latin America.

The table also shows that the data reported vary considerably across countries. For instance, in Argentina lenders are required to report data on defaults, arrears, loan exposure, interest rates and guarantees. In Germany, only loan exposure and guarantees are reported; in Belgium, only defaults and arrears.

PCRs invariably specify a reporting threshold, but this varies considerably. In most of Europe, PCRs effectively collect information only on relatively large loans to businesses, but in Belgium and France they also cover consumer loans. The threshold is highest in Germany and lowest in Belgium. Clearly, the higher the threshold set

\footnotetext{
${ }^{7}$ In some countries, public registers also exist for unpaid IOUs and tax liens.

${ }^{8}$ In Argentina not only financial institutions but also the general public can access the PCR. In Chile the data are also made available to a private credit bureau. In Israel and Greece a database on large loans is collected for supervisory reasons only by the central bank, but this information is not made available externally.

${ }^{9}$ Hong Kong is currently setting up a PCR.
} 
Table 2

Public credit registers around the world

\begin{tabular}{|c|c|c|c|c|c|}
\hline Country & Starting date & $\begin{array}{l}\text { Number of } \\
\text { subjects } \\
\text { covered } \\
(\mathrm{yr})\end{array}$ & $\begin{array}{l}\text { Credit } \\
\text { reports } \\
\text { issued } \\
\text { (millions) }\end{array}$ & $\begin{array}{l}\text { Minimum } \\
\text { reporting } \\
\text { threshold } \\
\text { (US\$) }\end{array}$ & $\begin{array}{l}\text { Data } \\
\text { reported by } \\
\text { participating } \\
\text { institutions }\end{array}$ \\
\hline Argentina & 1991 & $4,000,000$ & N/A & 50 & $\mathrm{D}, \mathrm{A}, \mathrm{L}, \mathrm{G}$ \\
\hline Australia & None & & & & \\
\hline Austria & 1986 & 55,585 (1997) & 10,267 (1997) & 430,700 & $\mathrm{~L}, \mathrm{G}$ \\
\hline Belgium & 1985 & $\begin{array}{l}360,000 \text { house- } \\
\text { holds ( } 1997) \text {, } \\
400,000 \text { firms } \\
(1990)\end{array}$ & $\begin{array}{l}3,550,000 \\
\text { households } \\
\text { (1997) }\end{array}$ & $\begin{array}{l}223 \text { for house- } \\
\text { holds, } 27,950 \\
\text { for firms }\end{array}$ & $\begin{array}{l}\mathrm{D}, \mathrm{A} \text { (con- } \\
\text { sumer and } \\
\text { mortgage } \\
\text { credit only) }\end{array}$ \\
\hline Bolivia & 1989 & N/A & $1,300,000$ & 0 & $\begin{array}{l}\mathrm{D}, \mathrm{A}, \mathrm{L}, \mathrm{R}, \mathrm{G}, \\
\text { repayments }\end{array}$ \\
\hline Brazil & 1997 & N/A & $\begin{array}{l}4,000,000 \\
\text { households } \\
6,000,000 \\
\text { firms }\end{array}$ & 0 & $\mathrm{D}, \mathrm{A}, \mathrm{L}$ \\
\hline Canada & None & & & & \\
\hline Chile & 1975 & $\begin{array}{l}2,200,000 \\
\text { households } \\
600,000 \text { firms } \\
(1998)\end{array}$ & $\begin{array}{l}\text { Information } \\
\text { transferred to } \\
\text { a private credit } \\
\text { bureau }\end{array}$ & 0 & $\begin{array}{l}\mathrm{D}, \mathrm{A}, \mathrm{L}, \mathrm{G}, \text { risk } \\
\text { class, sector, } \\
\text { type of } \\
\text { debt, etc. }\end{array}$ \\
\hline Colombia & 1994 & N/A & N/A & N/A & N/A \\
\hline Denmark & None & & & & \\
\hline Finland & None & & & & \\
\hline France & $\begin{array}{l}1989 \text { for } \\
\text { households, } \\
1984 \\
\text { for firms }\end{array}$ & $\begin{array}{l}370,000 \\
(1990)\end{array}$ & $\begin{array}{l}5,400,000 \\
(1990)\end{array}$ & $\begin{array}{l}118,293 \\
(1990)\end{array}$ & $\begin{array}{l}\mathrm{D}, \mathrm{A} \text { for } \\
\text { households, L, } \\
\mathrm{G} \text {, undrawn } \\
\text { credit facilities } \\
\text { for firms }\end{array}$ \\
\hline Germany & 1934 & $1,200,000$ & $1,800,000$ & $1,699,800$ & $\mathrm{~L}, \mathrm{G}$ \\
\hline Greece & None & & & & \\
\hline Egypt & None & & & & \\
\hline Hong Kong & None & & & & \\
\hline India & None & & & & \\
\hline Ireland & None & & & & \\
\hline Israel & 1975 & 15,000 & N/A & 169,500 & $\mathrm{D}, \mathrm{L}$ \\
\hline Italy & 1964 & $\begin{array}{l}2,200,000 \text { (1994), } \\
6,536,914 \text { (1998) }\end{array}$ & $\begin{array}{l}1,400,000 \\
(1994)\end{array}$ & $\begin{array}{l}0 \text { for bad } \\
\text { loans, } 86,010 \\
\text { for other } \\
\text { loans }\end{array}$ & $\mathrm{D}, \mathrm{A}, \mathrm{L}, \mathrm{G}$ \\
\hline Japan & None & & & & \\
\hline Jordan & 1966 & N/A & 14,300 & 42,065 & A, L \\
\hline Kenya & None & & & & \\
\hline Mexico & 1964 & $\begin{array}{l}260,000 \\
(1997)\end{array}$ & $\begin{array}{l}129,870 \\
(1997)\end{array}$ & 20,111 & $\begin{array}{l}\mathrm{D}, \mathrm{A}, \mathrm{L}, \text { eco- } \\
\text { nomic activity } \\
\text { of debtor, type } \\
\text { of credit }\end{array}$ \\
\hline
\end{tabular}

Netherlands None

New Zealand None 
Table 2 (continued)

\begin{tabular}{|c|c|c|c|c|c|}
\hline Country & Starting date & $\begin{array}{l}\text { Number of } \\
\text { subjects } \\
\text { covered } \\
(\mathrm{yr})\end{array}$ & $\begin{array}{l}\text { Credit } \\
\text { reports } \\
\text { issued } \\
\text { (millions) }\end{array}$ & $\begin{array}{l}\text { Minimum } \\
\text { reporting } \\
\text { threshold } \\
\text { (US\$) }\end{array}$ & $\begin{array}{l}\text { Data } \\
\text { reported by } \\
\text { participating } \\
\text { institutions }\end{array}$ \\
\hline Nigeria & None & & & & \\
\hline Norway & None & & & & \\
\hline Peru & 1968 & $\begin{array}{l}1,920,000 \\
(1998)\end{array}$ & N/A & 0 & $\mathrm{D}, \mathrm{A}, \mathrm{L}, \mathrm{G}$ \\
\hline Philippines & None & & & & \\
\hline Portugal & 1977 & $\begin{array}{l}2,469,120 \\
(1998)\end{array}$ & N/A & 5 & $\begin{array}{l}\mathrm{D}, \mathrm{A}, \mathrm{L}, \mathrm{G} \text {, } \\
\text { undrawn credit } \\
\text { facilities }\end{array}$ \\
\hline Singapore & None & & & & \\
\hline South Africa & None & & & & \\
\hline South Korea & None & & & & \\
\hline Spain & 1983 & $\begin{array}{l}4,600,000 \\
(1991)\end{array}$ & $\begin{array}{l}758,000 \\
(1997)\end{array}$ & $\begin{array}{l}6720 \text { for } \\
\text { residents, } \\
336,000 \text { for } \\
\text { non-residents }\end{array}$ & $\begin{array}{l}\mathrm{D}, \mathrm{A}, \mathrm{L}, \mathrm{G}, \\
\text { regional, } \\
\text { sectoral and } \\
\text { currency risk }\end{array}$ \\
\hline Sri Lanka & 1990 & N/A & $\begin{array}{l}102,175 \\
(1997)\end{array}$ & $\begin{array}{l}1493 \text { for bad } \\
\text { loans, } 7465 \text { for } \\
\text { other loans }\end{array}$ & $\mathrm{D}, \mathrm{A}, \mathrm{G}$ \\
\hline Sweden & None & & & & \\
\hline Switzerland & None & & & & \\
\hline Taiwan & None & & & & \\
\hline Thailand & None & & & & \\
\hline Turkey & None & & & & \\
\hline UK & None & & & & \\
\hline Uruguay & 1984 & N/A & $\begin{array}{l}8000 \\
(1997)\end{array}$ & N/A & $\mathrm{D}, \mathrm{A}, \mathrm{L}$ \\
\hline US & None & & & & \\
\hline Venezuela & $1980 \mathrm{~s}$ & N/A & N/A & 0 & $\mathrm{D}, \mathrm{A}, \mathrm{L}$ \\
\hline Zimbabwe & None & & & & \\
\hline
\end{tabular}

Figures are based on a questionnaire sent to central banks. The data reported to the register are defaulted loans (D), arrears (A), total loan exposure (L), interest rates (R), and guarantees (G). The exchange rates used to convert the minimum reporting threshold into dollars are those of September 1, 1998.

by regulators, the fewer the borrowers covered and the credit reports issued, as we see in Table 2. The threshold also demarcates the segment in which private credit bureaus operate without competition from the PCR: above the threshold, credit bureaus have to take into account that lenders can also turn to the public register's reports.

A major emerging problem for PCRs is posed by the growing integration of national credit markets, particularly within the European Union. As of 1998, PCRs are strongly if not exclusively oriented to their respective domestic markets. For instance, Italian banks are required to report to the Italian PCR loans made by their foreign branches. But these loans are not reported to the host-country PCRs. Similarly, Italian companies can borrow abroad without being reported to the Italian PCR. The integration of capital markets thus implies that PCRs are losing the capacity to provide full, accurate and reliable information on the overall credit situation. 
Efforts made by the EU commission to set up an international credit reporting system have not met with success so far owing to the differences between systems which are already in place in the individual countries and the fact that countries without a central credit register are unwilling to set up a credit reporting system at the national level. However, European PCRs are planning to establish cooperative agreements to provide lenders with cross-border information. As the legal requirements for this exchange of information have not been met by all EU countries, and since technical and organizational problems have not been solved, it is not possible to say when this cooperation will become effective. In the longer run, it is well possible that the PCRs will be gradually displaced by the growth of private, multinational credit bureaus. Since only eight EU countries have PCRs and even they find it difficult to agree on a common set of rules, the second outcome seems more likely. ${ }^{10}$

\section{The effect of information sharing on bank lending}

The data described in Sections 3 and 4 can be used to relate bank lending to measures of the activity of credit bureaus and public credit registers, such as their presence, the quality of information collected, and the number of years they have been in operation. This exercise poses several data problems. First, missing values and nonresponses limit the number of countries for which we have data on information sharing. Second, data on default rates are hard to collect and compare internationally. Third, one must control for other legal and institutional determinants of lending and defaults, and these variables are only available for a few countries. Finally, there is a causality issue that our reduced form approach cannot address. Theoretical models show that information sharing may increase lending and reduce defaults. The same models, however, also suggest that where credit is more abundant lenders have a stronger incentive to set up a credit bureau.

The first row of Table 3 reports the ratio between bank lending to the private sector and GDP in a sample of 40 countries. Data refer to 1994-1995. The countries are divided into three groups, depending on whether prior to 1994: (i) no private credit bureau existed, (ii) only black information was exchanged, or (iii) both black and white information was shared. Bank lending is about twice as large in countries where information is shared, irrespective of the type of information exchanged. However, the correlation may be spurious: information sharing is found in countries with higher GDP per capita, better law enforcement and poorer safeguards for creditor rights, variables that may well themselves be correlated with bank lending. To control for their effect on bank lending, we turn to regression analysis.

To explain international differences in lending activity, we regress the ratio of bank lending to GDP on the log of output in 1994-1995, the growth rate of output in 1970-1993, and indicators of rule of law, creditor rights and legal origin of the commercial code of each country (see Appendix for sources and definitions). We

\footnotetext{
${ }^{10}$ In fact, it may be already occurring: in October 1998, the main Italian credit bureau (CRIF) announced a link-up with other European credit bureaus.
} 
Table 3

Information sharing and credit market performance: descriptive statistics

\begin{tabular}{lclcc}
\hline Variable & $\begin{array}{l}\text { Total } \\
\text { sample }\end{array}$ & $\begin{array}{l}\text { No information } \\
\text { sharing }\end{array}$ & $\begin{array}{l}\text { Black informa- } \\
\text { tion only }\end{array}$ & $\begin{array}{l}\text { Black and white } \\
\text { information }\end{array}$ \\
\hline Bank lending/GDP (\%) & 60.53 & 31.10 & 67.57 & 66.42 \\
Credit risk & 7.77 & 15.20 & 5.11 & 7.14 \\
Log GDP & 7.19 & 5.96 & 6.77 & 7.79 \\
GDP growth rate (\%) & 3.45 & 4.53 & 2.87 & 3.38 \\
Rule of law & 7.24 & 4.80 & 8.14 & 7.59 \\
Creditor rights & 2.15 & 3.14 & 2.20 & 1.83 \\
French origin & 0.40 & 0.43 & 0.20 & 0.48 \\
German origin & 0.12 & 0.00 & 0.00 & 0.22 \\
Scandinavian origin & 0.10 & 0.00 & 0.30 & 0.04 \\
English origin & 0.37 & 0.57 & 0.50 & 0.26 \\
Number of observations & 40 & 7 & 10 & 23 \\
\hline
\end{tabular}

Countries are divided according to the type of information exchanged via private credit bureaus or public credit registers, based on Tables 1 and 2. Black information only is 1 if prior to 1994 private credit bureaus and/or PCRs exchange black information, and 0 otherwise. Black and white information is 1 if prior to 1994 credit bureaus or PCRs exchange black and white information. The Bank Lending - GDP ratio is the ratio of bank claims on the private sector to GDP in 1994-95. The credit risk indicator is based on the International Country Risk Guide Financial Indicator (ICRGF), and ranges from 0 to 50 (maximum risk). The total number of observations for credit risk is 35. See Appendix for sources and definition of other variables. Country included are: Argentina, Australia, Austria, Belgium, Brazil, Canada, Chile, Denmark, Egypt, Finland, France, Germany, Greece, Hong Kong, Ireland, Israel, Italy, Japan, Kenya, Mexico, Netherlands, New Zealand, Nigeria, Norway, Peru, Philippines, Portugal, Singapore, South Africa, South Korea, Spain, Sri Lanka, Sweden, Switzerland, Thailand, Turkey, UK, Uruguay, US, Zimbabwe.

use a baseline specification similar to that used by La Porta et al. (1997) and by Levine (1998), who find that the breadth of the credit market is positively correlated with good law enforcement and protection of creditor rights. They also find that the historical origins of national legal systems are associated with significant differences in lending activity: French (civil law) and Scandinavian systems are associated with a lower ratio of private debt to GNP than English (common law) and German systems. La Porta et al. (1997) measure the size of the credit market by the sum of bank debt of the private sector and outstanding non-financial bonds divided by GNP, while Levine (1998) uses bank lending from 1976 to 1993 . We also focus on bank lending, because credit bureaus and PCRs can be expected to affect primarily banks' policies. ${ }^{11}$ Information on bond issuers is instead produced by credit rating agencies and generally publicly available.

Column (1) of Table 4 presents the estimates of the baseline specification for the 40 countries for which we have complete records. The estimates confirm previous findings that rule of law and creditor rights are important determinants of bank lend-

\footnotetext{
${ }^{11}$ Since all countries have public registers for real estate collateral, one should distinguish between debt collateralized by real estate and other loans. However, separate information on mortgage lending is not available. In a few countries there are data on housing mortgage loans alone, but even for these countries data are not fully comparable and often do not include mortgage lending to business. So we must rely on aggregate bank loans.
} 
Table 4

Effect of information sharing on bank lending/GDP

\begin{tabular}{|c|c|c|c|c|c|}
\hline \multirow[t]{2}{*}{ Variable } & \multicolumn{3}{|c|}{ Ordinary least squares } & \multirow{2}{*}{$\begin{array}{l}\text { Trimmed } \\
\text { regression } \\
\text { (4) }\end{array}$} & \multirow{2}{*}{$\begin{array}{l}\text { Robust } \\
\text { regression } \\
(5)\end{array}$} \\
\hline & (1) & (2) & (3) & & \\
\hline \multirow{4}{*}{$\begin{array}{l}\text { GDP growth } \\
\text { rate } \\
\text { Log GDP }\end{array}$} & 2.61 & 2.93 & 2.17 & 0.30 & -1.19 \\
\hline & $(0.85)$ & $(0.89)$ & $(0.62)$ & $(0.15)$ & $(-0.68)$ \\
\hline & 5.30 & 4.96 & 2.23 & 5.08 & 5.34 \\
\hline & $(1.73)$ & (1.51) & $(0.61)$ & $(2.17)$ & $(2.00)$ \\
\hline \multirow[t]{2}{*}{ Rule of law } & 7.47 & 6.25 & 7.72 & 4.90 & 4.87 \\
\hline & $(3.14)$ & $(2.46)$ & $(3.64)$ & (3.94) & (2.89) \\
\hline Creditor & 6.58 & 8.32 & 5.27 & 8.57 & 9.96 \\
\hline rights & $(2.12)$ & $(2.76)$ & (1.07) & $(2.55)$ & $(3.23)$ \\
\hline \multirow[t]{2}{*}{ French origin } & & & -7.01 & 0.80 & 2.46 \\
\hline & & & $(-0.65)$ & $(0.12)$ & $(0.31)$ \\
\hline German & & & 26.67 & 19.83 & 14.66 \\
\hline origin & & & $(1.24)$ & (1.82) & $(1.42)$ \\
\hline Scandinavian & & & -44.46 & -29.98 & -29.22 \\
\hline origin & & & $(-3.18)$ & $(-2.52)$ & $(-2.59)$ \\
\hline Black informa- & & 24.77 & 29.38 & 36.42 & 36.46 \\
\hline tion only & & $(1.52)$ & $(1.82)$ & $(4.90)$ & $(3.50)$ \\
\hline Black and white & & 23.18 & 15.65 & 26.95 & 27.23 \\
\hline information & & $(2.38)$ & $(1.43)$ & $(5.00)$ & $(2.92)$ \\
\hline Constant & -54.86 & -67.93 & -42.65 & -60.02 & -60.64 \\
\hline & $(-2.71)$ & $(-3.03)$ & $(-1.22)$ & $(-3.32)$ & $(-2.96)$ \\
\hline Adjusted $R^{2}$ & 0.46 & 0.50 & 0.67 & 0.81 & - \\
\hline $\begin{array}{l}\text { Number of } \\
\text { observations }\end{array}$ & 40 & 40 & 40 & 36 & 40 \\
\hline
\end{tabular}

Bank lending to GDP is the ratio of bank claims on the private sector to GDP in 1994-95. Black information only is 1 if prior to 1994 private credit bureaus and/or PCRs exchange black information, and 0 otherwise. Black and White Information is 1 if prior to 1994 credit bureaus or PCRs exchange black and white information. See Appendix for sources and definition of other variables. White-corrected standard errors are used in the OLS estimates. The trimmed regression in column (4) excludes influential observations (Thailand, Hong Kong, South Korea and Switzerland). The robust regression of column (5) first calculates Huber weights based on absolute residuals and then regresses again until convergence using those weights. $T$-statistics are reported in parentheses. The complete list of countries is reported in the legend of Table 3 .

ing. In the specification of column (2) we add two variables intended to proxy for the type of information sharing. The first variable equals 1 if either private credit bureaus, PCRs or both exchange only black information, and 0 otherwise. The second equals 1 if either private credit bureaus, PCRs or both exchange black as well as white information. As discussed in Section 2, black information alone may have a disciplinary effect on borrowers, but the availability of both black and white information enhances the banks' screening ability.

Both coefficients are positive and that of black and white information is statistically different from zero at the $2 \%$ level. The point estimates indicate that with information sharing the ratio of bank to GDP is more than $20 \%$ points higher. In column (3) we add the legal origin dummies to the list of regressors. Due to the correlation between creditor rights and legal origin and to the fewer degrees of freedom, the 
coefficients of the creditor rights variable and the information sharing dummies are now less precisely estimated.

The correlation between bank lending and information sharing might be due to some influential observations. We check the residuals of the regression to single out potential outliers. The observations with relatively high values of the Cook's Distance are Thailand, Hong Kong, South Korea, and Switzerland. ${ }^{12}$ The results of the trimmed estimation obtained by dropping these observations are reported in column (3): the coefficients of both information sharing variables increase, and so does their precision. ${ }^{13}$ We further check our results by using an estimator that is robust to the presence of influential values, and report the results in column (4). The two dummies for information sharing are both statistically different from zero at the $1 \%$ significance level.

In principle, private credit bureaus may impact credit markets differently compared to public credit registers. As explained in Section 4, PCRs have universal coverage but provide more aggregated data compared to credit bureaus and collect data only for loans above a statutory threshold. We test for this differential impact by adding separate dummies for information exchanged by credit bureaus. The coefficients of these variables (not reported for brevity) are not statistically different from zero. This suggests that private and public information sharing arrangements are substitutes, an issue that will be further investigated in Section 7.

We also experimented with other indicators of information sharing: the per capita number of credit reports provided by private credit bureaus and/or PCRs (using the data in Tables 1 and 2) and the number of years from the establishment of the earliest bureau of which we have knowledge. The latter variable is based on the assumption that time in existence may correlate with the size of the industry's databases and the reliability of its storage and processing techniques. The coefficients of these additional indicators are not statistically different from zero (regressions are not reported for brevity).

\section{The effect of information sharing on defaults}

Investigating the correlation between information sharing and default rates is complicated by the unavailability of internationally comparable data on defaults. The fraction of non-performing loans is hard to compare across countries, because of international differences in the definition of a non-performing loan. Moreover, this variable cannot be found for many countries. ${ }^{14}$ The proportion of loan loss provisions is

\footnotetext{
${ }^{12}$ Bollen and Jackman (1990, pp. 265-266) suggest to analyze the impact of observations with Cook's Distance exceeding $4 / n$, where $n$ is the number of observations in the sample.

${ }^{13}$ Similar results are obtained by including a dummy for East-Asian countries in an OLS regression on the complete sample. In contrast, observations for Latin American countries do not appear to be a cluster of influential values. A dummy for Latin America carries a statistically insignificant coefficient and its inclusion leaves other coefficient almost unaffected.

${ }^{14}$ Non-performing loans are available only for a very limited number of countries in the balance sheets data of the IBCA BankScope data set. In our case, this would reduce the sample size to 18 observations, only 1 of which refers to a country without any form of information sharing.
} 
an even less reliable measure of the default rate. Loan loss provisions are not only distorted by differences between national accounting standards and prudential banking regulations, but also by their highly discretionary nature: to a large extent, banks can decide how much to allocate to provisions in anticipation of future losses.

We believe that a survey-based measure of credit risk obtained from an homogeneous sample of respondents is a more reliable proxy for the default rate, and therefore rely on the "credit risk" indicator based on the International Country Risk Guide (ICRG) survey of leading international bankers (Erb et al., 1996). We rescale the original ICRG indicator so that that our credit risk variable ranges from 0 to 50 (maximum risk). Aside from its international comparability, this indicator has the advantage of being based on ex-ante attitudes of potential lenders.

The shortcoming of the ICRG indicator is that it is imperfectly correlated with the likelihood of default on bank loans, since it also reflects other risks. It is a composite, equal-weighted indicator of five types of financial risk. Respondents are asked to rate the risk of loan default or restructuring, delayed payment of suppliers' credits, repudiation of contracts by governments, losses from exchange controls, and expropriation of private investments.

The descriptive evidence in the second row of Table 3 reveals that countries where information is shared have lower than average credit risk. In Table 5 we investigate if the descriptive evidence is confirmed by regression analysis.

The OLS estimates in columns (1) and (2) of Table 5 indicate that slow GDP growth rate and poor rule of law predict higher credit risk. The coefficients of the information sharing dummies are large and negative, and significantly different from zero at the $10 \%$ level or better. According to the point estimates of these regressions, the presence of information sharing reduces credit risk by 3 or 4 points, between one third and one half of the sample average of credit risk ( 7.77 from Table 3$)$. Information sharing is also associated with lower non-performing loans, to the extent that the latter is correlated with our indicator of credit risk. For the 18 countries for which both indicators are available, the correlation between credit risk and the ratio of non-performing loans to total loans is 0.59 , and is statistically different from zero. A simple regression for these 18 countries predicts that a 3 -points reduction in our credit risk indicator translates into a $1 \%$ point reduction in the fraction of non-performing loans, to be compared with a sample average of $4.7 \%$.

As in the previous section, we are concerned that our estimates may be driven by the presence of influential observations. The trimmed regression reported in column (3) is based again on the Cook's Distance statistics, and excludes Thailand, Hong Kong, South Korea, and Switzerland. The size and precision of the coefficient estimates are only slightly attenuated. The pattern of results in the robust regression of column (4) is similar. The explanatory power of the regressions is unchanged if we add separate indicators for information provided by private credit bureaus. We take this as evidence for the substitutability of private and public information sharing arrangements.

The results of this section indicate that default rates are negatively correlated with information sharing indicators. The effect is economically significant, but not always precisely estimated, since its statistical significance varies depending on the estimation method. 
Table 5

Effect of information sharing on credit risk

\begin{tabular}{lcccc}
\hline Variable & \multicolumn{2}{l}{ Ordinary least squares } & $\begin{array}{l}\text { Trimmed } \\
\text { regression }\end{array}$ & $\begin{array}{l}\text { Robust } \\
\text { regression } \\
(4)\end{array}$ \\
\cline { 2 - 5 } & $(1)$ & $(2)$ & -0.63 & -0.61 \\
\hline GDP growth rate (\%) & -0.63 & -0.56 & $(-2.59)$ & $(-2.06)$ \\
Log GDP & $(-2.05)$ & $(-1.97)$ & -0.04 & -0.21 \\
& -0.57 & -0.34 & $(-0.14)$ & $(-0.43)$ \\
Rule of law & $(-1.21)$ & $(-0.74)$ & -1.88 & -1.71 \\
& -1.65 & -1.67 & $(-8.34)$ & $(-5.45)$ \\
Creditor rights & $(-4.31)$ & $(-4.74)$ & -0.17 & -0.09 \\
& -0.45 & -0.09 & $(-0.47)$ & $(-0.17)$ \\
French origin & $(-1.07)$ & $(-0.17)$ & 1.33 & 1.04 \\
& & 0.90 & $(1.41)$ & $(0.70)$ \\
German origin & & $(0.73)$ & -1.96 & -2.46 \\
& & -2.76 & $(-1.81)$ & $(-1.41)$ \\
Scandinavian origin & & $(-2.32)$ & $(1.62$ & 2.23 \\
& & $(1.19$ & $-3.18)$ & $(1.18)$ \\
Black information only & -4.26 & -4.54 & -3.78 \\
& $(-1.91)$ & $(-2.15)$ & -2.15 & $(-1.89)$ \\
Black and white & -2.99 & -2.40 & -2.22 \\
information & $(-1.76)$ & $(-1.37)$ & $(-1.65)$ & $(-1.23)$ \\
Constant & 30.59 & 27.51 & 26.27 & 26.49 \\
& $(9.67)$ & $(8.90)$ & $(9.74)$ & $(7.09)$ \\
$R^{2}$ & 0.78 & 0.84 & 0.90 & - \\
Number of observations & 35 & 35 & 30 & 35 \\
\hline
\end{tabular}

The credit risk indicator is based on the International Country Risk Guide Financial Indicator (ICRGF), and ranges from 0 to 50 (maximum risk). Black information only is 1 if prior to 1994 private credit bureaus and/or PCRs exchange black information, and 0 otherwise. Black and white information is 1 if prior to 1994 credit bureaus or PCRs exchange black and white information. See Appendix for sources and definition of other variables. White-corrected standard errors are used in the OLS estimates. The trimmed regression in column (4) excludes influential observations (Philippines, Nigeria, Thailand, Brazil and Australia). The robust regression of column (5) first calculates Huber weights based on absolute residuals and then regresses again until convergence using those weights. $T$-statistics are reported in parentheses. Countries included are the same as in the legend of Table 3 except: Egypt, Israel, Kenya, Sri Lanka, Uruguay.

\section{Substitution between private and public information sharing arrangements}

One finding of the previous two sections is that private and public information sharing arrangements have no differential effects on lending activity and proxies for default rates. One way to interpret this finding is that public credit registers and private credit bureaus are substitutes. If this is true, in countries where credit bureaus are already present the benefit of establishing a public credit register is negligible. Conversely, its benefit should be high where credit bureaus are absent, other things equal.

In this section we investigate whether the absence of private credit bureaus prompts regulators to establish public credit registers or to widen the scope of their operation. If PCRs are created to remedy the failure of private credit bureaus to 
arise, the pre-existence of a credit bureau should be negatively related to the presence of a PCR.

In estimating this relationship, one should control for the severity of moral hazard in the credit market. As discussed in Section 2, in the presence of moral hazard information sharing mechanisms increase borrowers' incentives to repay, and they can lead to a welfare gain. ${ }^{15}$ Therefore, if credit bureaus fail to arise spontaneously (say, because of coordination problems), the case for the creation of a PCR by a regulator is particularly strong in countries in which debtors' opportunistic behavior plagues credit relations and where institutions afford a weaker protection to creditor rights. We control for these factors using the rule-of-law index and the creditor rights variable in La Porta et al. (1997).

The correlations between these variables are displayed in Table 6 . The conditional averages in Panel A show that a private credit bureau already existed in only $30 \%$ of the countries where there is a PCR, against 65\% where there is none. Also, PCRs tend to be formed in countries where creditor rights are less protected (1.59 versus 2.50) and there is less respect for the law (the rule-of-law variable is 6.67 against 7.34). They are also more likely to be found in countries whose legal system derives from the French civil code tradition (the French-origin dummy is 0.71 against 0.19 ).

To control for the impact of all these variables, we estimate Probit regressions where the presence of a PCR is the dependent variable. The results, displayed in columns (1) and (2) of Panel B, show that the probability of the presence of a PCR is significantly and negatively related to the pre-existence of a credit bureau. The coefficient indicates that pre-existence of a private credit bureau lowers the probability of establishing a PCR by $40 \%$. If the legal origin dummies are not introduced in the regression, the creditor-rights variable also appears with a negative and significant coefficient. When the origin dummies are added as explanatory variables in column (2), the coefficient of creditor rights is still negative but not precisely estimated, whereas the French-origin dummy takes a large, positive and statistically significant coefficient. The reason is that creditor rights is negatively correlated with French origin; that is, the countries whose legal system is rooted in the French civil code are also those that afford the weakest legal protection to creditors. Finally, the coefficient of the rule-of-law variable is close to zero.

As we saw in Section 4, a key parameter in the design of a PCR is the threshold above which data on loans must be reported by credit institutions. The lower the threshold, the more accurate and comprehensive the account of past credit history that the PCR can provide to lenders. Therefore the threshold effectively measures the boundaries of the PCR operation.

In columns (3) and (4) we report estimates of Tobit regressions where the threshold - measured in thousands of US dollars - is related to the same set of regressors as in Probit regressions. The reason for using Tobit rather than OLS estimation is that the threshold is not defined in countries where there is no PCR. For these countries,

\footnotetext{
${ }^{15}$ Padilla and Pagano (2000) show that, if these mechanisms are appropriately designed, borrowers' effort to perform is closer to the socially optimum level.
} 
Table 6

Determinants of the presence of public credit registers

\begin{tabular}{|c|c|c|c|c|}
\hline Variable & Total sample & PCR present & \multicolumn{2}{|c|}{ PCR absent } \\
\hline \multicolumn{5}{|c|}{ Panel A. Descriptive statistics } \\
\hline Creditor rights & 2.14 & 1.59 & \multicolumn{2}{|l|}{2.50} \\
\hline Rule of law & 7.08 & 6.67 & \multicolumn{2}{|l|}{7.34} \\
\hline $\begin{array}{l}\text { Pre-existence of a private } \\
\text { credit bureau }\end{array}$ & 0.51 & 0.29 & \multicolumn{2}{|l|}{0.65} \\
\hline English origin & 0.38 & 0.12 & \multicolumn{2}{|l|}{0.54} \\
\hline French origin & 0.39 & 0.71 & \multicolumn{2}{|l|}{0.19} \\
\hline German origin & 0.14 & 0.11 & \multicolumn{2}{|l|}{0.15} \\
\hline Scandinavian origin & 0.09 & 0.06 & \multicolumn{2}{|l|}{0.12} \\
\hline Number of observations & 43 & 17 & \multicolumn{2}{|l|}{26} \\
\hline \multirow[t]{2}{*}{ Variable } & \multicolumn{2}{|c|}{ Probit regressions } & \multicolumn{2}{|c|}{ Tobit regressions } \\
\hline & (1) & (2) & (3) & (4) \\
\hline \multicolumn{5}{|l|}{ Panel B. Regression results } \\
\hline Creditor rights & $\begin{array}{c}-0.16 \\
(-2.37)\end{array}$ & $\begin{array}{c}-0.07 \\
(-0.81)\end{array}$ & $\begin{array}{r}4,321.06 \\
(2.16)\end{array}$ & $\begin{array}{r}2,204.75 \\
(0.95)\end{array}$ \\
\hline Rule of law & $\begin{array}{c}-0.01 \\
(-0.11)\end{array}$ & $\begin{array}{c}-0.01 \\
(-0.09)\end{array}$ & $\begin{array}{r}-121.96 \\
(-0.13)\end{array}$ & $\begin{array}{r}361.37 \\
(0.36)\end{array}$ \\
\hline $\begin{array}{l}\text { Pre-existence of a private } \\
\text { credit bureau }\end{array}$ & $\begin{array}{l}-0.39 \\
(-2.24)\end{array}$ & $\begin{array}{c}-0.41 \\
(-2.04)\end{array}$ & $\begin{array}{r}12,469.24 \\
(2.31)\end{array}$ & $\begin{array}{r}13,169.54 \\
(2.13)\end{array}$ \\
\hline French origin & & $\begin{array}{c}0.49 \\
(3.35)\end{array}$ & & $\begin{array}{r}-11,988.97 \\
(-1.65)\end{array}$ \\
\hline German origin & & $\begin{array}{c}0.57 \\
(1.77)\end{array}$ & & $\begin{array}{r}-15,803.28 \\
(-1.72)\end{array}$ \\
\hline Scandinavian origin & & $\begin{array}{c}0.48 \\
(1.16)\end{array}$ & & $\begin{array}{r}-10,200.36 \\
(-0.96)\end{array}$ \\
\hline Number of observations & 43 & 43 & 41 & 41 \\
\hline
\end{tabular}

Countries are divided according to the presence of public credit registers, based on Table 2. Presence of a PCR is 1 if the register is operating in 1998, 0 otherwise. Pre-existence of a private credit bureau is 1 if at least one private credit bureau was in operation before the establishment of the PCR, 0 otherwise. Other data are taken from La Porta et al. (1997). See Appendix for sources and definition of the variables. In the Probit regressions the dependent variable is the presence of a PCR prior to 1998 (see Table 2). In the Tobit regression the dependent variable is the PCR minimum reporting threshold (see Table 2). The Probit coefficients indicate the effect of the variable on the probability of establishment of a PCR. T-statistics are reported in parentheses. Countries included in the Probit estimation are the same as in the legend of Table 3 plus Colombia, India and Taiwan. Countries included in the Tobit estimation are the same as in the legend of Table 3 plus India and Taiwan and excluding Uruguay.

we set the threshold at an arbitrarily large positive number. As a result, the distribution of the dependent variable features lower and upper truncation. Countries where the threshold is set at the arbitrary positive number do not operate a PCR. Countries where the threshold is set at zero have the most comprehensive PCR. For intermediate values, the lower the threshold the broader the scope of the PCR activity.

The pattern of results is similar to that of the Probit regressions, once one takes into account that in this case the signs are predicted to be opposite. In particular, the pre-existence of a private credit bureau raises the threshold by about 13 million US dollars. Since obviously no existing PCR has such enormous threshold, the interpre- 
tation of this number is that pre-existence of a credit bureau effectively discourages the creation of a PCR altogether.

In summary, the historical experience is consistent with the hypothesis that the establishment of PCRs has been largely motivated by the "substitution" role. First, they have often been created to make up for the lack of private credit bureaus. Where the market alone has not produced information sharing, governments have felt they had to take the initiative. Second, PCRs have been introduced to compensate, at least partly, for the weak protection that the state offered to creditors' interests, and thus to remedy heightened moral hazard in lending.

\section{Conclusions}

In many countries lenders communicate data concerning their customers' creditworthiness to one another or can access databases that help them assess credit applicants. However, the type and quantity of data shared by lenders, and the information-sharing mechanism, vary greatly. Often lenders agree to exchange of information spontaneously, via information brokers such as credit bureaus. In other cases they are obliged to do so by the authorities via public credit registers. The empirical literature has not contributed much to our knowledge of this phenomenon and of its relevance to credit market performance. The predictions of the theory offer some guidance as to the impact of information sharing on default rates and lending activity. However, its predictions are partly ambiguous, and therefore it is especially important to turn to the data in order to investigate the relation between information sharing and credit market performance.

Here, we systematically document private and public information-sharing arrangements around the world and analyze their effects on the credit market as well as the reasons for their emergence. The empirical analysis builds upon a new, specially designed data set mainly collected via questionnaires. We find that the breadth of credit markets is associated with information sharing. Total bank lending to the private sector scaled by GNP is larger in countries where information sharing is more solidly established and intense. This relation exists even when one controls for other economic and institutional variables, such as country size and growth rate, and variables capturing respect for law and the protection of creditor rights. We also find evidence, in accordance with the theory, that public and private information sharing mitigates credit risk, that we consider a proxy for default rates. This evidence is somewhat weaker, however, perhaps owing to the quality of our proxy for defaults.

Our data also show that the impact of private arrangements to share credit information is similar to that of public credit registers. In fact, where private credit registers already existed, PCRs are less likely to be established. Conversely, governments are likely to step in with forced information sharing in countries where private information-sharing arrangements have not arisen. They are also more likely to do so where creditor rights are poorly protected.

We regard this paper as a first step in the empirical analysis of the effects of information sharing on credit markets. The pervasiveness and intensity of this 
information exchange warrants much more thorough inquiry into its effects on the lending policies of banks and the conduct of borrowers. There is still no microeconomic evidence on this issue. We also lack accounts of the impact of these arrangements in developing countries, where in many cases they are just being established. It is ironic that private credit bureaus and public credit registers know so much about us while we still know so little about them.

\section{Acknowledgements}

We thank Jorge Padilla, Andrew Powell, Robert Townsend and seminar participants at the Banque de France, Western Finance Association, Barcelona, Buenos Aires, Salerno, Bologna, Napoli and at the Bank of Italy for their comments. We also thank Enrico Lodi, Margaret Miller, Joe Pegues, Beatrice Rubini, Gennaro Scarfiglieri and Flavia Terribile for their precious help in gathering data, and Lia Ambrosio for excellent research assistance. Tullio Jappelli acknowledges financial support from the Inter-American Development Bank, the OECD, and the Fondation Banque de France. Marco Pagano acknowledges grants by the Consiglio Nazionale delle Ricerche and the Italian Ministry for Universities and Scientific Research.

\section{Appendix A. Definition of variables used in Tables 3-6}

Bank lending Claims of banks on private sector, 1994-1995 average.

Source: International Financial Statistics (line 32d)

Credit risk It is based on the International Country Risk Guide Financial Indicator (ICRGF). The indicator is constructed on the basis of a survey of leading international bankers, who are asked to rate each country on a scale of 0 to 10 each of the following 5 risks: default or unfavorable loan restructuring, delayed payment of suppliers' credits, repudiation of contracts by governments, losses from exchange controls, expropriation of private investments. The original index scales from 0 to 50 (maximum creditworthiness). We define credit risk as 50 minus the original index, so that 50 represents maximum risk. Credit risk refers to October 1995. Source: Erb et al. (1996), Table 4, Series ICRGF

Creditor An index aggregating creditor rights. The index aggregates rights various rights that secured creditors might have in bankruptcy, liquidation and reorganization. Restrictions on the managers' ability to seek unilateral protection from creditors, mandatory dismissal of management in reorganizations, lack of automatic stay on assets, and absolute priority for secured creditors all contribute to this index. The index ranges from 0 to 4 .

Source: La Porta et al. (1997) 
Log GDP Logarithm of the gross domestic product in 1992-93. Gross domestic product is expressed in 1990 million dollars. Source: International Financial Statistics, line 99b for GDP and aa for exchange rates

GDP growth Average annual percent growth of per capita gross domestic product, for the period 1970-1993. Source: International Financial Statistics

Legal origin Identifies the legal origin (English, German, French, Scandinavian) of the company law or commercial code of each country. Source: La Porta et al. (1997)

Rule of law Assessment of the law-and-order tradition in the country. Average of the $1982-95$ period. Scale from 0 to 10 with lower scores for less tradition of law and order. Source: La Porta et al. (1997)

\section{Appendix B. Questionnaire directed to private credit bureaus}

Aim of the survey. This questionnaire is part of a research project that aims at understanding the frequency, determinants and consequences of information sharing arrangements in credit markets. This questionnaire is directed to managers of credit bureaus.

Confidentiality. The researchers carrying out this project guarantee complete confidentiality in the use of the data collected in the survey. Data and results based on the survey will always be presented in tabular form and at a level of aggregation that will safeguard the confidentiality of individual banks.

Please enclose any published or official material that you feel would be relevant to understand the operation of credit bureaus in your country.

\section{B.1. Description of your credit bureau}

Town where headquarters is located:

The credit bureau is owned by:

A group of banks

A group of other financial intermediaries

Individual share-holders

Foreign-owned (majority stake foreign-owned)

The credit bureau is

A company run for profit

A cooperative enterprise or consortium of lenders

A semi-public institution

Other (please indicate) 
Indicate who originally started the credit bureau:

Private entrepreneurs

Consortium of lenders

Government agency

Other (please indicate)

The credit bureau operates:

At multinational level

At national level

At regional or provincial level

B.2. Scale of operations

Personal sector Business sector

Year started operating

Number of records in your files in 1990

Number of records in your files in 1996

Credit reports issued in 1990

Credit reports issued in 1996

Credit reports issued in 1990 as \% of all those

issued in your country in that year

Credit reports issued in 1996 as \% of those

issued in your country in that year

If the credit bureaus started operating after 1990, please supply information on credit reports and number of records in the first year of the operation of the credit bureau.

\section{B.3. Sources of information}

Please rank the importance of the following as sources of information for your credit reports on a 1 to 3 increasing scale: $1=$ not used or rather unimportant, $2=$ important; $3=$ crucially important.

\begin{tabular}{lll}
\hline & Personal sector & Business sector \\
\hline Banks & & \\
Other financial institutions & \\
Credit card companies & \\
Central Credit Register & \\
Public records & \\
Tax files & \\
Other: (please indicate) & \\
\hline
\end{tabular}


B.4. Data supplied by lenders

Which type of data are provided by lenders to your credit bureau?

\begin{tabular}{l}
\hline \multicolumn{1}{c}{ Personal sector Business sector } \\
\hline Defaulted loans \\
Arrears \\
Total loan exposure \\
Characteristics of borrowers ${ }^{\mathrm{a}}$ \\
Other: (please indicate) \\
${ }^{\mathrm{a}}$ For households: employment status, marital status, age, income, assets, etc.; for \\
firms: line of business, balance sheet data, personal information about directors, \\
share-ownership structure, etc.
\end{tabular}

\section{B.5. Reciprocity}

Do you apply a principle of reciprocity with your clients (i.e., do you supply information only to those who supply it to you)?

\section{YES $\square \quad$ NO}

If yes, is there an explicit agreement between you and lenders to exchange information?

YES $\square \quad$ NO

What happens if lenders do not comply with the reciprocity agreement (i.e. supply late or incorrect information)?

\section{B.6. Credit bureaus in your country}

Please list the other main credit bureaus that operate in your country:

Please describe briefly the evolution of the credit bureau industry in the last 10 years in your country (growth and problems of the industry, process of concentration, etc.)

\section{B.7. Public credit registers}

Please indicate if a Public Credit Register exists in your country and, if so, how it affects your operations. (By a P.C.R. we mean a publicly managed database, which forcibly collects data about loans from banks to supply it under request from other banks.)

\section{B.8. Privacy laws}

If laws protecting consumer privacy exist in your country, what do they require? How do these laws affect the operation of your company? 


\section{Appendix C. Questionnaire directed to central banks}

This questionnaire is part of a research project that aims at understanding the frequency, determinants and consequences of information sharing arrangements in credit markets. By Public Credit Register we mean a public database managed by the Central Bank or some other government institution, which forcibly collects information about loans from banks and makes it available under request from other banks via credit reports.

\section{C.1. Management of the public credit register (PCR)}

Is the PCR operated by the Central Bank or by another Government agency?

\section{C.2. Activity}

Year in which the PCR was established

Number of subjects in the file of the PCR

Number of credit reports issued by the PCR to banks and other lending institutions in 1997 (1996 if not available)

Minimum reporting threshold (specify currency units)

Lenders required to supply data (banks, finance companies, etc.)

Is participation compulsory? (yes/no)

\section{C.3. Data reported by participating institutions to the PCR}

Defaulted loans

Arrears

Total loan exposure

Interest rates

Other (please indicate)

C.4. Access to data in the PCR files

Government

Participating financial institutions

Private Credit Bureaus

General public

Other (please indicate) 


\section{C.5. Private credit bureaus}

Please list the names of the private credit bureaus that operate in your country.

\section{C.6. Privacy laws}

Please mention if privacy laws exist and, if so, how they affect the operations of the PCR and of private credit bureaus.

\section{References}

Bollen, K.A., Jackman, R.W., 1990. Regression diagnostic: An expository treatment of outliers and influential cases. In: Fox, J., Long, J.S. (Eds.), Modern Data Analysis. Sage, Newbury Park, CA, pp. $257-291$.

Erb, B.C., Harvey, C.R., Viskanta, T.E., 1996. Political risk, economic risk, and financial risk. Financial Analyst Journal (November/December), 29-45.

Jappelli, T., Pagano, M., 2000. Information sharing in credit markets: The European experience. Università di Salerno, CSEF Working Paper no. 35, http://www.dise.unisa.it/WP/wp35.pdf.

La Porta, R., Lopez-de-Silanes, F., Shleifer, A., Vishny, R.W., 1997. Legal determinants of external finance. Journal of Finance 52 (3), 1131-1150.

Levine, R., 1998. The legal environment, banks, and long-run economic growth. Journal of Money, Credit and Banking 30 (3, part 2), 596-613.

Padilla, A.J., Pagano, M., 1997. Endogenous communication among lenders and entrepreneurial incentives. The Review of Financial Studies 10 (1), 205-236.

Padilla, A.J., Pagano, M., 2000. Sharing default information as a borrower discipline device. European Economic Review 44 (10), 1951-1980.

Pagano, M., Jappelli, T., 1993. Information sharing in credit markets. Journal of Finance 43 (5), 1693 1718. 